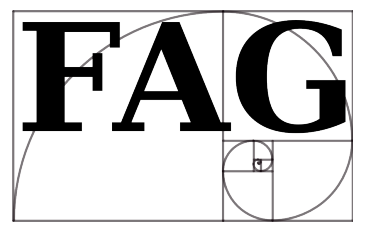

Filozoficzne Aspekty Genezy — 2013, t. 10

http://www.nauka-a-religia.uz.zgora.pl/images/FAG/2013.t.10/art.02.pdf

\author{
Robert Piotrowski
}

\title{
Mutschler o fizyce i religii
}

\author{
Hans-Dieter Mutschler, Fizyka i religia. \\ Perspektywy oraz granice dialogu, przeł. Józef Bremer, \\ Wydawnictwo WAM, Kraków 2007, s. 380.
}

Omawiana książka jest przekładem pracy Physik und Religion. Perspektiven und Grenzen eines Dialogs (Wissenschaftliche Buchgesellschaft, Darmstadt 2005). Jest to druga książka Mutschlera opublikowana po polsku. Przekład ponownie powierzono ks. Józefowi Bremerowi, jak w przypadku kompromitacji pt. Wprowadzenie do filozofii przyrody (2005). ${ }^{1}$ Przypomnijmy, iż była to nibypolskojęzyczna wersja książki Mutschlera Naturphilosophie. Trudno orzec, czy thumacz sam zdołał poprawić swoją polszczyznę, czy może zatrudniono lepszego redaktora - tak czy inaczej efekt jest odrobinę lepszy, choć i tak niezadowalający. Dalej widoczne są nieporadności. Błędy w terminologii matematyczno-fizycznej budzą wręcz zdziwienie, skoro z życiorysu thumacza wynika, że ukończył on Politechnikę Śląską. Miejscami wyraźnie prześwituje niemiecki szyk wyrazów, widoczne są nieporadności leksykalne oraz błędy merytoryczne.

Oto kilkanaście przykładów: „Maya” (np. s. 12; zamiast Maja, nie wiedzieć czemu zawsze w cudzysłowie); „książkę Bohma o «Implizite Ordnung»” (s. 12); „do prawdziwej platońskiej nauki o schodzeniu” (s. 75); „wcześnie orientującą się na fizyce” (s. 184); „Galileo Galileusza” (s. 208); „odnosi się do intrinsisch

\footnotetext{
${ }^{1}$ Por. Robert Piotrowski, „Filozofia przyrody po niemiecku”, Filozoficzne Aspekty Genezy 2012 , t. 9, s. 271-276, http://www.nauka-a-religia.uz.zgora.pl/index.php?action=tekst\&id=239 (01.03.2013).
} 
wolnych od wartości przedmiotów” (s. 211); „pod silnie dzisiaj ekspandującą «teorię kompleksowości»” (s. 211); „faszystowsko pieniącym się psychoanality-

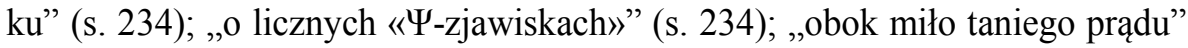
(s. 235); „W scientific community istnieje” (s. 260); „common-sense wariant świata” (s. 266 i 269); ,potoczno-światowe przekonania” (s. 267); „impuls” (s. 274; zamiast „pęd”); „frekwencja” (s. 274 i 306; zamiast „,częstotliwość”); „tangencyjną” (s. 300; zamiast „tangencjalną” albo „styczną”); „formuła” (np. s. 305; zamiast „wzór”), „noetic world” (s. 332), „teoremu «gnozeologicznego pożądania»" (s. 353).

Wzory (s. 88, 89 i 274) są źle poskładane. Na stronie 305 znajdują się dwa koszmarki imitujące wzór oscylatora harmonicznego oraz równanie Fouriera. Albo nie ozdabia się w ten sposób tekstów humanistycznych, albo trzeba się nauczyć składu matematycznego. Ostatecznie, książkę nienajlepiej się czyta.

W ponad 350-stronicowym tomie brak indeksów, choćby osobowego, a przede wszystkim porządnie zrobionej bibliografii. Redakcja oszczędziła sobie wysiłku, przeklejając spis literatury z oryginału, dodając jedynie w nawiasach informacje o ewentualnych przekładach polskich (i to nie wszystkich). Tymczasem znaczna część pozycji, z których korzystał autor, to również thumaczenia, tylko z angielskiego na niemiecki, których Polak chcący skorzystać z literatury źródłowej wyszukiwać nie będzie — należało podać dane oryginałów.

Praca składa się ze wstępu, sześciu rozdziałów i epilogu. Rozdział pierwszy dotyczy filozofii Plancka, drugi platonizmu Carla Friedricha von Weizsäckera, następnie autor zajmuje się przedstawicielami neopozytywizmu (Carnapem, Quinem i Stegmüllerem). W rozdziale 4. referuje debatę Junga z Paulim. W ostatnich dwóch rozdziałach znajdujemy autorskie przedstawienie sytuacji nauki nowoczesnej oraz relacji między nauką a religią. Zgodnie z tytułem, osią książki jest ocena prób powiązania koncepcji fizycznych z religijnymi. Autor ocenia większość z nich negatywnie, miejscami z widoczną irytacją. De gustibus non est disputandum, ponadto $\mathrm{w}$ wielu przypadkach nastawienie Mutschlera jest całkiem uzasadnione.

Autor, zgodnie z deklaracją poczynioną we Wprowadzeniu do filozofii przyrody, woli patrzeć na świat oczyma Arystotelesa, któremu założono Kan- 
towskie okulary. A mimo to Stagirytę pozostawia w tle. Bohaterem - i to negatywnym — jest właśnie Platon. Jak wiadomo, niektórzy arystotelicy mają Platona za arcywroga, odpowiedzialnego za późniejsze myślozbrodnie Kartezjuszów, Kantów i Marksów. Takie nastawienie (mimo wspomnianych okularów) wyczuwa się także u Mutschlera. Przynosi to uszczerbek książce, w której zabrakło $\mathrm{z}$ tego powodu rozwinięcia wątków mających znaczenie dla filozofii fizyki, a nie związanych bezpośrednio z walkami frakcyjnymi między spadkobiercami Akademii. Jednym $\mathrm{z}$ nich jest teologia naturalna, lekceważąco skwitowana wzmianką na s. 331-332.

Jak już mieliśmy okazję napisać - poszukiwanie adekwatnej filozofii to problem sam w sobie. Są dziedziny, do których jakaś doktryna zdaje się wręcz przykrojona, i takie, do których nie wiadomo, co i jak przyłożyć. Do biologii pasuje arystotelizm, do filozofii kultury ewolucjonizm i to raczej lamarckizm, niżeli darwinizm, do logiki i matematyki bezwzględnie platonizm, nieźle sprawdzający się też w językoznawstwie, o czym świadczy choćby tradycja tej dziedziny w Rosji (także sowieckiej). Nie sugerujemy bynajmniej, że łatwe przypasowanie interpretacji ostatecznie załatwia sprawę, dokładniejsze omówienie tego problemu z oczywistych względów odkładamy do oddzielnego artykułu.

Tak czy inaczej dzieje fizyki i religii świadczą o istnieniu dziedzin, których nie przyodzieje się w żadne gotowe wdzianko filozoficzne. W przypadku religii jest to w miarę oczywiste, jeżeli chodzi o fizykę, niektórym wciąż się zdaje, iż dla niej albo uda się stworzyć jakąś adekwatną wersję mechanicyzmu, albo też filozofia znajdzie się w obiecywanej przez samych fizyków ogólnej teorii zupełnie wszystkiego. Tymczasem matematyzacja fizyki pcha filozofię tej ostatniej właśnie w platonizm, czemu sprzyjają niekiedy skłonności samych fizyków. Bóg okazuje się Naczelnym Programistą, Stroicielem Strun Kosmicznych, Wielkim Geometrą. W midraszach twierdzi się, iż stworzył On świat, zaglądając do Tory, którą skądinąd wciąż regularnie czyta - jeśli uwierzyć filozofującym fizykom, to w międzyczasie zmienił zestaw lektur na traktaty o supersymetrii.

Mutschler nie lubi też holizmu (pkt. 2.3 zatytułował „O pustce holizmu”), co warto podkreślić ze względu na dhugą tradycję myślenia holistycznego u Niemców. „Myślenie całościowe” uznaje za modę analogiczną do fali werbalnej cybernetyzacji (s. 95) — która w latach 60. dwudziestego wieku poważnie 
zaszkodziła reputacji prawdziwej cybernetyki. Faktycznie, ślady każdej takiej fali rychło zmywa kolejna i dziś holizm zastępują baśnie o chaosie, nieliniowości, splątanych kwantach i wszechświatach równoległych.

Fizyka, powiada autor, „nie nadaje się ani na teistyczną, ani ateistyczną instancję odwoławczą" (s. 177-178). Odległość między fizyką a religią powoduje niemal ich całkowitą nieporównywalność (s. 342). Próba przerzucenia jakiegoś mostu wymaga odwołania się do metafizyki, jednak trzy możliwości skonstruowania takowej, które Mutschler wylicza, są dla niego samego niezadowalające. Przedstawia owe warianty w niezbyt przejrzysty sposób, wymieniając: „metafizykę koncypowaną", metaphysica specialis, metaphysica generalis. W pierwszym przypadku, jak rozumiemy, chodzi o metafizykę skrojoną na zamówienie, istotnie ufundowaną na podstawach religijno-filozoficznych. Tymczasem teologiczne koncepcje czasoprzestrzeni i materii nie mają z fizycznymi „nic wspólnego” (s. 343). Swoją drogą w „Epilogu” autor twierdzi, jakoby Biblia nie zawierała prawie żadnej metafizyki. Ciekawe, skąd mu się to wzięło, wszak w Piśmie znajdujemy całkiem sporo konkretnej metafizyki - i tej antropologicznej, i tej kosmologicznej. Atoli, czym innym jest treść świętego tekstu, a czym innym jej teologiczna rekonstrukcja. Metaphysica specialis to metafizyka zaczerpnięta z samych podstaw fizyki, tym bardziej nie wystarczająca, wreszcie metaphysica generalis okaże się pewnie oporna na próby inkorporacji nowoczesnych koncepcji fizycznych.

Pewną szansę w połączeniu analogizującego i wieloznacznego myślenia religijnego z jednoznacznym i ilościowym dyskursem nauk ścisłych Mutschler widzi w odwołaniu się do pośrednictwa sztuki. Niestety, nie byliśmy w stanie zapoznać się z esejem Botho Straußa, „Beginnlosigkeit”, który wywarł takie wrażenie na autorze omawianej książki. W sumie bardzo to wszystko humanistyczne, ale jak dla nas wątpliwe. Nie sposób ignorować trudności na drodze interpretacji religii, lecz nie ma co ich jeszcze sztucznie zwiększać. Mutschler to bez wahania czyni, odwołując się między innymi do irracjonalizmu Kierkegaarda.

Na koniec jeszcze kilka uwag. W przypisie 102 na s. 197 czytamy, jakoby Church i Turing w roku 1936 dowiedli, ,że dla elementarnej logiki nie może być żadnej procedury decydowania”. Przede wszystkim chodzi nie o żadną „procedurę decydowania" - bo to anglicyzm, od decisability — tylko o roz- 
strzygalność, czyli istnienie skończonego algorytmu, po którego wykonaniu wiedziałoby się, czy dana formuła jest na gruncie danej teorii tautologią, czy też nie (Entscheidungsproblem). Church i Turing, owszem, dowiedli nierozstrzygalności, lecz nie „logiki elementarnej”, tylko rachunku predykatów pierwszego rzędu. Swoją drogą ów rachunek ma słabszą własność półrozstrzygalności, da się bowiem w skończonej liczbie kroków potwierdzić, że jakaś formuła tautologiczna istotnie takową jest. A jeżeli „logika elementarna” miałaby oznaczać klasyczny rachunek zdań, to oczywiście mamy do czynienia z teorią rozstrzygalną.

Na tej samej stronie, w trakcie rozważań o Gödlu i Hilbercie, pojawia się ni stąd ni zowąd rewelacja: „Przez resztę życia Frege był zdruzgotany krytyką Russella - zaczął chorować i czuł się całkowicie rozbity”. Chodzi o rzekomy efekt zapoznania się z antynomią Russella. Biografowie potwierdzają, iż było to dla Fregego nieprzyjemne, lecz ów dowiedział się o paradoksie już w roku 1902 od samego odkrywcy, zaś chorować zaczął po śmierci żony w dwa lata później, zawsze będąc depresyjnym introwertykiem. ${ }^{2}$

Autor przeczy sobie, raz pisząc, że Pauli został profesorem dwa lata po habilitacji (s. 226), a raz, jakoby profesury ,nigdy nie objął i pozostał zamiast tego przy nauce szkolnej [?]" (s. 230). Faktycznie w roku 1923 został profesorem na Uniwersytecie Hamburskim, a w 1928 na Politechnice Federalnej w Zurychu.

Sami opowiadamy się za umiarem stylistycznym, lecz zarzut postawiony Stegmüllerowi jako reprezentantowi logicyzmu jest czepiactwem. Czemuż nieco ekscentryczne przykłady Stegmüllera miałyby świadczyć o tajemniczym pokrewieństwie „pomiędzy nekrofilią a wyostrzonym logicyzmem” (s. 220)?

Robert Piotrowski

\footnotetext{
${ }^{2}$ Por. np. Michael Potтer, „Introduction”, w: Michael Potter et al. (eds.), The Cambridge Companion to Frege, Cambridge University Press, Cambridge 2010, s. 20-22.
} 